\title{
HARMFULNESS OF THE AUTISTIC OBJECT TO ITS INDISPENSABILITY FOR AUTISM CLINICALLY IN PSYCHOANALYSIS
}

Paula Ramos Pimenta, Jésus Santiago and Ana Lydia Santiago

Paula Ramos Pimenta

Faculdade de

Ciências Médicas de Minas Gerais (FCMMG), Belo Horizonte/MG, Brasil.

Jésus Santiago Universidade Federal de Minas Gerais (UFMG), Departamento de Psicologia, Belo Horizonte/MG, Brasil.

Ana Lydia Santiago Universidade Federal de Minas Gerais (UFMG), Programa de Pós-Graduação em Educação: Conhecimento e Inclusão Social, Belo Horizonte/ MG, Brasil.
ABSTRACT: In this paper we examine the concept of the autistic object in the psychoanalytic treatment of individuals with autism. Comparison is made between the concepts of two authors, Frances Tustin and Jean-Claude Maleval, both dedicated researchers in the area. Tustin identifies the function of autistic objects in the treatment of the autistic body image. Differentiation between autism and schizophrenia is presented. Maleval enhances the perception of Tustin, by highlighting the role of dynamism in autistic objects, as a promoter of the libidinal animation of autists. The paper concludes by assessing the consequences of privileging one or another theoretical conception of the autistic object clinically.

Keywords: Psychoanalysis. Autistic object. Treatment. Autism. Schizophrenia.

RESUMO: Da nocividade do objeto autístico à sua imprescindibilidade para a clínica do autismo em psicanálise. O artigo procura salientar o lugar especial do objeto autístico no tratamento psicanalítico dos autistas. Para fundamentá-lo, coteja a concepção de dois autores que se dedicaram à sua investigação, Frances Tustin e Jean-ClaudeMaleval.Tustinidentifica afunção dos objetosautísticos no tratamento da imagem corporal do autista. Uma diferenciação entre autismo e esquizofrenia é apresentada. Maleval amplia a percepção de Tustin, destacando a função de dinamismo dos objetos autísticos, promotora de uma animação libidinal do autista. O artigo conclui por avaliar as consequências de se privilegiar uma ou outra concepção teórica do objeto autístico para a clínica com autistas. Palavras-chave: Psicanálise. Objeto autístico. Tratamento. Autismo. Esquizofrenia.

DOI - http://dx.doi.org/10.1590/S1516-14982016002013 
R ecently, psychoanalysis has found itself with the necessity to justify to

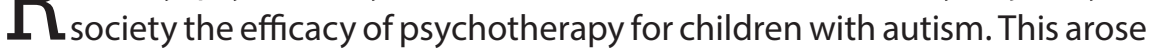
in the $90 \mathrm{~s}$, with a growing reaction of psychiatry against the prescription of behavioral treatment. This movement ended with a policy proposal in the form of a bill presented to the French National Assembly to ban psychoanalysis in the treatment of autism ${ }^{1}$. As a result, psychoanalysts with long-term clinical experience mobilized to demonstrate to the public how psychoanalysis facilitates treatment of autism and submitted a public petition with the purpose of blocking implementation of the legislation.

What we find, once again, is the polarization between the behavioural approach and the psychoanalytical approach for these children. Distinct epistemological principles underlie an educational proposal for the autistic, modelling their behaviour misfits, or understanding the validity of the oddities of these behaviours. One of the most dissonant items between the two approaches refers to conduct toward the autistic subject. This behavioural objectification promotes the disconnection of the autist to the world around them, as will be clarified later. With educational approaches, interventions are aimed at phasing out these character obstacles, in order to favour skill acquisition.

Psychoanalysis, in turn, takes it as fundamental to pay attention to the spontaneous interests of the autistic. However, within the concept of the autistic object differences remain as to the place assigned to it but not to its indispensability for conducting treatment and to the understanding of the therapeutic harmfulness of these objects. Two authors have devoted themselves to detailing the clinical implications of the autistic object, polarizing the axis of discussion, highlighting then the relevance of the elaborations formulated by Frances Tustin and Jean-Claude Maleval.

Examining the theoretical internal disagreements enables the psychoanalyst who deals with autism to reflect about the understanding of the place of autistic objects in the treatment by developing logical interventions.

\section{FRANCES TUSTIN AND SECONDARY ENCAPSULATED AUTISM}

The pioneering English psychotherapist Frances Tustin (1913-1994), trained in Kleinian theory, formed part of a group of post-Freudian psychoanalysts. As such, she shares the developmental approach of the psyche, conceiving the existence of a preverbal stage in early childhood, interpreted by the object relationship.

\footnotetext{
${ }^{1}$ At the start of 2012, the deputy Daniel Fasquelle, of UMP francesa (Union pour un Mouvement Populaire), proposed legislation to prohibit psychoanalysis. Cf. http://www.lemonde. fr/idees/chronique/2012/01/27/une-loi-pour-interdire-la-psychanalyse-dans-l-autisme_1635287_3232.html. Acessed 3 March, 2012.
} 
Her work was dedicated especially to the study of autism. ${ }^{2}$ Examining her clinical methodology, Tustin proved to beopen to diverse interpretation. Shewas influenced by the thinking of the child psychiatrist and Hungarian psychoanalyst, based in the United States, Margaret Mahler (1897-1985), and the English paediatrician and psychoanalyst Donald Winnicott (1896-1971), originally kleinian but she followed an independent path.

The influence of Mahler's ideas about the primitive autistic and symbiotic phases of the child led Tustin to describe normal primary autism (NPA) where "the baby cannot recognize external objects, when provided with individual characteristics that distinguish them." (Tustin, 1972/1975, p. 110). NPA could derive from abnormal primary autism (APA) where mother and child were differentiated only fragmentally due to the lack of a minimum external care or the lack of something that would be essential for the baby to use such care. The majority remain in NPA which provides a development stop at a primitive stage, which Tustin described as secondary encapsulated autism (SEA).

Among the various autistic states of its initial development, it is SEA that Tustin equates to Kanner's Primitive Infantile Autism. "Early childhood autism belongs to SEA group and childhood schizophrenia to Secondary Regressive Autism." (TUSTIN, 1972/1975, p. 141). Secondary Regressive Autism (SRA) — could be dormant in SEA, and is distinguished by having been a period of relative normality before the onset of symptoms. The SRA group shows confusion of thought, while the SEA child presents with inhibition of thought.

Later, Tustin (1986/1990) modified her conception of NPA, claiming it always to have been a pathological state. This position was radically highlighted in her last work, published in 1993, which had the suggestive title "The perpetuation of an error" (TUSTIN, 1995).

Some differentiation, drawn by Tustin, between SEA and SRA compared autism and schizophrenia. She describes autistics as child-shells or crustaceans (TUSTIN, 1972/1975, p 113;.. 1981/1984, p 39), for making the choice of a protective shell against non-self aspects, which evidenced their separation from others, prompting a shock or scare ${ }^{3}$ and a consequent sensation of destruc-

\footnotetext{
${ }^{2}$ The term "autism" is here consistent with the design of Kanner, its proposer. Among the characteristics described by child psychiatrist, it highlights the autistic loneliness with "extreme autistic closure"; the absence of language communication function even in those children "talking"; an 'anxious obsession to stay ", with the imperative that there are no changes, the minimum possible, in your environment; and a good relationship with objects as opposed to bad relationships with people. Cf. KANNER, L. (1943/1997). Autistic disturbances of affective contact, in ROCHA, P. S. (Eds.). Autisms. Sao Paulo: Escuta, p. 111-170.

${ }^{3}$ In order given by Freud, the scare - Schreck - is distinguished from fear and distress. The scare takes entirely the psychic apparatus and is economically disorganized, since he is not prepared to receive external stimuli. This is the mechanism of trauma. Cf. FREUD,
} 
tion. Stereotypical and repetitive motor behaviours, result in a dissociated state similar to self-hypnosis, which leads to the hiding of non-self objects from the outside world. Autists create their refuge in an inanimate world of people and things, unable to distinguish their own bodies. This barrier leads them to avoid eye contact and speech.

Unable to differentiate between animate and inanimate, makes things of objects and people, experienced as autistic holes. "Things have 'holes', not 'wounds'." (TUSTIN, 1981/1984, p. 61). They are children who have never experienced missing a significant person, only emptiness and nothing, which are different." (Tustin, 1981/1984, p. 61). Similarly, they do not experience pain and suffering. Suffering arises from the wound and brings evidence of any representation.

(...) The traumatized patient experiences "pain, but not suffering". They feel pain. The pain is in them. They are involved in pain. Autistic children were insulated from the pain through autistic procedures (...) In therapy with these children, when pain is experienced and reduced autistic insulation begins to be modified. This means that suffering begins to be felt. The injured child becomes more open to healing by the therapist and able to sustain sufferingthroughloss (sic). (TUSTIN, 1995, p.77).

Tustin in her conception of autism, notes that the autistic child looks like a frozen automaton (TUSTIN, 1995, p. 74), with a delusion of powerful control over the outside world. Deliberate impermeability to the outside brings with it the absence of motivation to learn or acquire skills.

Tustin evaluated the autistic object for its important role in autism. It is described as being part of the body of the child or of the outer world they experience as part of themselves. The role of the autistic object is to "neutralize any perception of existence - too intolerable and threatening - a 'not-me'." (TUSTIN, 1972/1975, p. 76). With the use of this "sensation-object" (TUSTIN, $1981 / 1984$, p. 136), the child avoids the unbearable frustration. Therefore they prevent "the development of thoughts, memories and imagination that, in normal development, compensates to some extent for the inevitable lack of complete satisfaction that is inherent in the human being." (TUSTIN, 1981/1984, pp. 142-143).

As a result, the author observes that the autistic child does not play or draw ${ }^{4}$ which is a result of an obstacle to imaginative capacity; one symptom of the

S. (1920/1976) "Beyond the Pleasure Principle," in Edição standard brasileira das obras psicológicas completas de Sigmund Freud, Vol. XVIII. Rio de Janeiro: Imago, p. 23-24.

4 "Encapsulated of theshell type do not draw in the early stages before psychotherapy has begun to take effect," specifies Tustin (1981/1984, p. 63). 
triad of autism components, proposed by the British psychiatrist Lorna Wing ${ }^{5}$ that supports the psychiatric classification of DSM-IV. The autist loses the practical stage of normal childhood, where, in the absence of the mother, the baby exercises acts of babbling, sucking and mouthing, "early learning experiences associated with games." (TUSTIN, 1981/1984, p. 141). ${ }^{6}$

Tustin maintains that the autist lives in a two-dimensional world, evidenced by surface qualities of texture and shape. There would be, for them, no knowledge "of the outsides and insides" (TUSTIN, 1981/1984, p. 162). Thus, when the child transposes an object, it is placed there in the sense of covering, being wrapping and protecting, but not of "being inside".

The schizophrenic has understood and already transited, albeit confusingly, the three-dimensions of insides and outsides. They have made this advance because the "perception of their physical limits has been for longer than those [children] presenting with SEA." (TUSTIN, 1972/1975, p. 100). This acquisition could be inferred as a body outline. The schizophrenic, builds his greatest resourcefulness in the things and people from the outside world, unlike the autistic. On the contrary, the schizophrenic child acts responsively, talking and maintaining eye contact. "There is no doubt about deafness," indicates TUSTIN(1981/1984, p. 58). Their speech, however, is often poorly organized, long-winded and confusing. Rarely exhibits echolalia, but some children make the pronominal reversal. ${ }^{7}$ Their gaze seems to pierce, rather than to contemplate.

This opening slightly larger to the "non-self" makes the schizophrenic child feel the hole of bodily separation as a wound, which implies some representation. This symbolic potential, from a Kleinian understanding that Tustin introduces about the formation of symbols, leads the schizophrenic, unlike the autist, to draw and play during analysis, even if in a quite particular way.

\footnotetext{
${ }^{5}$ In 1988, Lorna Wing defined the basic symptom triad of autism, with disabilities in social relations, communication and imaginative capacity. This diagnostic approach was taken by subsequent psychiatric manuals as a pillar for their classifications. Cf. WING, L. (1993) "The continuum of autistic characteristics" in GAUDERER, E. C. (Ed.) Autism and other developmental delays. An update for those working in the area: Specialist parents. Brasilia: CORDE, p. 90-98.

${ }^{6}$ pointing in the same direction of the author, it is observed that, in Lacanian theory, the babbling is taken as index "lalangue" promoting enjoyment of the voice object, which is absent in autism.

${ }^{7}$ The pronoun reversal takes the child to be called as it is called by the other, in the third person.
} 


\section{THE AUTISTIC OBJECT: HARD AND HARMFUL}

An essential difference between autistic and schizophrenic children is shown in tustiana theory, by the choice of objects they make. Schizophrenics look for soft objects, which are "an amalgam of 'me' and 'not-me'" (TUSTIN, 1981/1984, p. 155). These, Tustin called "confusional objects." The objects of autistic children are, "fully experienced as 'me'" (TUSTIN, 1972/1975, p. 75), and are hard and unyielding objects. The type of object carried to bed by autists are trains and metal cars. Some autistic children may occasionally use soft objects, the confusional type but these "are exceptions in a collection of which the main part is the hard Autistic Object". (TUSTIN, 1981/1984, p. 156).

It is worth mentioning a recent observation of Laurent to highlight the importance of Tustin's work as a contribution to the discussion between autism and schizophrenia. The author notes that "there are certainly common things between the field of psychosis and autism. We should not assume that they are completely different fields, such as the perspective of psychopathology, but there is a specificity that should be considered." (LAURENT, 2012, p. 32). In the axis of the similarities and dissimilarities between autism and schizophrenia, Tustin inscribes the conjunction of confusional objects and autistic objects, to distinguish between them.

The confusional objects, such as autistic objects, are idiosyncratic to each child, which are compulsively used. They are not shared objects and their use does not reflect the way they are usually used. Both, moreover, prove to be "evasive distractions," bringing sensations of security and fun, that "distract from the child's tension associated with painful situations of 'non-self'." (TUSTIN, $1981 / 1984$, p. 156). Thus they resemble magical amulets, which expel danger, and totems, requiring obedience, worship or adoration.

A child may display several autistic or confusional objects, which are interchangeable. They are also objects "as if" (TUSTIN, 1981/1984, p. 161), for use as permanent replacements for aspects of parents as 'insurers'. Thus, advancing a barrier between the child and those who care for them. Collaborate with the avoidance of what TUSTIN (1981/1984, p 161) calls the "suspence": waiting for the satisfaction or realization of its impossibility. In Freudian terms, these objects prevent the institution of the reality principle. They reinforce the repetitioncompulsion, Tustin's adjectival "anti-life" denying "a life of the unexpected and with uncertainties, but with its unknown possibilities as well." (TUSTIN, $1981 / 1984$, p. 162). Paradoxically the "anti-life" aspect, is used to "force away a delirious 'death' — ('nothing' — 'annihilation')." (TUSTIN, 1981/1984, p. 143).

Behind the analogy between autistic and confusional objects, Tustin highlights their differences. The autistic object is felt as an extra part of the child's body, completely blocking the awareness of "not-me". While the confusional 
object only obscures the consciousness of "not-me", leaving a glimpse of their separation from the child's body, but cuddling it, in an attempt to hide.

Delirium sustained by mild confusional objects is to be caught up "in a veil, a mist or fog." (TUSTIN, 1981/1984, p. 163). Delirium nourished by hard autistic objects is encapsulation, with its impression that the impositions on the outside world are blocked. However, the autistic oscillates between complete absorption in themselves and sudden awareness of the "not-me", which are experienced as terrifying. Already soft objects of schizophrenic children keep them with a vague and perennial awareness of the difference between "me" and "not-me".

For Tustin (1981/1984), the primitive states of differentiation between "hard" and "soft" predate the distinction between "animate" and "inanimate". The choice of soft or hard objects is thus based. The preference of the schizophrenic for soft and flexible objects indicates a tenuous relationship with the animate-inanimate opposition. The radicality of autistic position to transform things and people into inanimate objects legitimizes their choice of hard and inflexible objects. The hardness of these objects reflects directly the autistic body state. "These children are 'in shock'. They are 'rigid with fear,' Tustin says (1995, p. 73). She adds:

Muscular hypertension associated with these stressful situations means that hard objects in the outside world seem appropriate to make the child feel protected from additional experiences that impinge on suffering. Such hard objects are felt as parts of their body. (TUSTIN, 1981/1984, p. 153)

The unbearable body tension makes the autist feel turgid and hard. They are then conceived as "not-me". An offshoot of the exercise of the effects of the mechanism proposed by Tustin infers that the choice of hard objects promotes external control of tension, which is not internally controllable. In this light, there is the hard autistic object with the function to find joy in itself but not in the body of the autistic, to use a Lacanian concept here is instructive. Following this reasoning - and extrapolating the indications of Tustin, despite them to base - the hard autistic object works as a double of the autist. It duplicates, the body of the autistic.

Autistic objects are static, in the sense of not open to new networks of association. On the contrary, they are used in a stereotypical and fixed manner, repetitively, with ritualistic and bizarre properties. The child has a rigidly intense concern with them, preferring to turn them obsessively, as they do with their own bodies. They are tangible objects, always present and dominated by sensations. With them, the autist focuses attention on familiar bodily sensations, repelling their "not-me" aspects. 
Rigid and inflexible objects are also brittle. A child grasps them firmly in situations experienced as dangerous, but this can come to break them. When this irreparable damage occurs, Tustin $(1972 / 1975,1981 / 1984)$ notes that autists come into a true state of despair. They then try to replace the damaged object.

A child of our clinic, who will be called Fabrizio, had spent a anxious busy week, without eating properly. When asked by the psychiatrist about possible changes that had occurred in the child's routine, the mother identified nothing. In a meeting with us it was suggested to look for changes, unimportant in their eyes, but that could have affected the child. She then remembered that the wreck of an old car that belonged to her grandfather had been taken from his back yard a week ago. Fabrizio had spent hours in it, pulling its wires and parts of the bodywork and the console. One of his autistic objects had been removed.

The moment he missed his autistic object, he was tense as if he had lost part of his body. One can understand that what is lost is the outer border that separates the enjoyment of the autistic tense body. However, through its characteristic replacement, its place can be taken by another object, experienced as being the same. "Encapsulated psychotic children are relatively indiscriminate" says Tustin (1981/1984, p. 132).

Autistic children are bonded to their objects. However autistic objects can be external objects or parts of the body of the child, as shown by Tustin (1981/1984) who includes the child's hands when used in stereotypical, non-functional ways. The use of the hands of others to make a gesture instead of the child's is interpreted by Tustin as turning the other person into an autistic object.

(...) Trying to turn the hand of another person into an autistic object, and using it as a thing devoid of life or without will is a powerful extension of themselves that will serve to carry out their wishes. For example, to open the door, turn on the light, pull the zipper up of their trousers, etc. - Which indicates at least some recognition of how the external world's objects operate. The inability to recognize this refers much more to the quality of 'not-me' in other people. (TUSTIN, 1972/1975, p. 81)

The very close relationship that autism promotes with the body of the people prompted the American psychoanalyst, based in England, Donald Meltzer (19222004) to coin the term "adhesive identification". Tustin, who was his supervisor in the well-known case of John, found it appropriate to use the terms "adhesiveat-oneness" or "adhesive equation" for such cases. He justified his choice by the fact that it is not permeated with an awareness of space, and associated with the notion of identification. This is based on empathy and requires a sense of space between the child and others, with support from a sense of identity. "In the adhesive-at-oneness, the child feels the same as anyone else and relates to that 
person as an inanimate object. This helps them to feel they exist. (...) It is more persistent than the 'adhesive identification'. "(TUSTIN, 1995, p. 74).

For her acute clinical perception, Frances Tustin is a reference for the treatment of autistic children. Despite the theoretical background of intermingled interpretations that imaginise the symbolic ${ }^{8}$, we see that her work brings an accurate observation of autism, with emphasis on her exquisite description of autistic objects.

However, the fundamental importance of these objects to the autist, marked in several passages of her work, she did not welcome them. For her, these objects are merely result in vicious circles of activity that intertwine, repeating endlessly. They are just a pseudo-protection (TUSTIN, 1981/1984, p. 136), impeding the development of a more genuine means of protection, that of relationships with people.

Her ambition of pursuing normal development that was halted in cases of autism, made it difficult to pursue achievable goals with these children, such as access to symbolization and interpersonal interaction without the use of autistic objects. "The psychotherapist's task is (...) contribute, in a word, so that transitional objects take the place of autistic objects and are ultimately replaced by the ability to form symbols (...)." (TUSTIN 1972 / 1975, p. 173). At another point, she states: "Only when introspective care can reach it [the child], are they able to start to abandon them." (TUSTIN, 1981/1984, p. 135). She adds, “(...) when autistic objects are abandoned, the child can start learning from experience and can be helped to make the distinctions and basic integrations that are natural to normal development." (TUSTIN, 1981/1984, p. 151).

The difficulty of putting into practice such a task is reflected in the absence of more precise details in her work. Tustin is contained in asserting that the therapist should not condone the use of objects by autistic children at the risk of leaving them "in the meshes of their disease" (TUSTIN, 1981/1984, p. 143). She advises educators and psychiatrists to become more active and rigorous in discouraging and even forbidding, pathological activities, to the point of taking away certain child objects.

But for those who are quick to conclude that Tustin advocates a particular intervention concerning these objects, the author demonstrates her susceptibility to autism pain, by holding up a caution against the analyst's interventions. For her, it takes

\footnotetext{
8 Tustin applies the same observation as Laurent on the practice of Melanie Klein, that "contrary to what is believed, it did not operate in psychoanalysis with the imaginary, but with the symbolic, like everyone else, imaginarizando it. (...) To imaginarizar symbolic, keeps sexual intercourse as possible. "Cf. LAURENT, É. (1984) «Lo Melanie knew ...», in LAURENT, É. Conceptions of healing in Psychoanalysis. Buenos Aires: Manantial, p. 63.
} 
(...) a lot of tact, patience and skill. It cannot be done abruptly and mechanically. We need to wait patiently for the appropriate time, when we can show them that humans, despite their unpredictability and mortality, provide more effective and sustained support than these objects imbued with excessive self-sensuality. (TUSTIN, 1981/1984, p. 148).

Firmness, accompanied by prudence. The developmental writing of Tustin precipitates in contradiction. That's what gives evidence from an observational point of view that autistic objects are used in "a useless and meaningless way"; but from the child's point of view, they are "absolutely essential" (TUSTIN, 1981/1984, p. 130).

Lacanian psychoanalysts considering this discrepancy have argued for the maintenance of autistic objects in treatment. Paired with their apparent harmfulness, manifested by their potentialalienating function, there is the understanding that some objects can sustain a social bond for autists.

This is also an indication of an autist. Temple Grandin (1997 apud MALEVAL, 2009, p 162) states that the fixations of the autistic and their obsessions should not to be rejected; on the contrary, this obsessive field should be extended, trying to guide the initial interest of the autistic, manifested in its fixations, towards constructive activities. For her, the fixations are a source of motivation for autists. ${ }^{9}$

\section{JEAN-CLAUDE MALEVAL AND THE DECLINATION OF THE AUTISTIC OBJECT}

Guided by the testimonies of autistics who had access to functional speech and communicated in writing about their way of life, the French psychoanalyst Jean-Claude Maleval considers that not all autistic objects have an alienating function as described by Tustin. The author relativizes these special objects and classifies them into two types, simple or complex, according to their contribution to pleasure, resulting in increased social interaction.

Two moments may circumscribe the theoretical development of Maleval. By the late 90 s, the author distinguished four types of autistic object that evolve with each other according to their participation in autistic defence. Today, the previous classification has been reformulated, resulting in two categories of autistic object: sufficient simple and complex.

In her first articulation Maleval (1997) used analysis of the most elaborate forms of defense by the subject - the same method, according to her, that

\footnotetext{
${ }^{9}$ GRANDIN, T. (1997) Penser en images. Paris: Odile Jacob, p. 115 cited Maleval, J.-C. (2009) "Les objets sont-ils autistiques complexes nocifs?" In Maleval, J.-C. (dir.) L'Autiste, son double objets et ses. Rennes, FR: Presses Universitaires de Rennes, p. 162. This book has not been translated into Portuguese and a French edition is not available.
} 
guided Freud and Lacan to untangle the mechanisms of psychosis — and notes that the function of insurer is essential with some objects and would be characteristic of autistic defence. Appropriating the expression used by Tustin for those special autistic objects, she proposed four stages of defense, in decreasing order of frustration: the "gross autistic object", the "unregulated autistic object", the "regulated autistic object" and the "regulating autistic object".

The "gross autistic object" is not the significantorganizer, buthelps the subject put order into the world, keeping the immutability and protecting them from the desire of the Other. Examples of this object are toys handled by children.

The "unregulated autistic object" the significant organiser, contributes to a more elaborate spatial world. The autistic subject either is bonded to the object under a transitivist relationship, or remains in a state of inertia, due to a "let fall" (laisser-tomber). Joey the machines on-off, the patient of Bruno Bettelheim, and lights-off, Stanley, the patient of Margaret Mahler, are examples of this type of object.

The "regulated autistic object" is an autistic-savant with skills including calendar and arithmetic calculation, among others. The regulated object also carries significance. Through them, the autistic-scholar is "taken en masse" (pris en masse), answering questions that test their exceptional skills in an almost hallucinatory way, without them apparently having to work.

The "regulating autistic object" brings the reference fixed by the signifier, but is detached for the autistic. Because of this relative distance, the subject can develop capacity to adapt to unforeseen situations. Examples of this higher progress of autism, include the slaughterhouse for cattle (trappe to bétail) and the book published Temple Grandin, such as Joey the electric machine .

The pressing further theoretical reelaboration originated from a necessarily conceptual precision employed by the author. It is the substitution of the concept signifier by the concept of sign.

In 1997, as noted in the descriptions of the four types of autistic object, Maleval believedthatthedefensepromoted byobjects developsthroughthejuxtaposition of signifier to them. Such contiguity produces an animation effect, bringing objects to the machine condition. The autistic machine, being a symbolic achievement, culminating in its essence, in a carrier object of significant organisers.

It some autists can see what Pierre Bruno called the "Other synthesis" (apud MALEVAL, 1997, p. 137). This concept was taken up by the elaborations of Maleval, occupying a special function to exist as a reservoir of the real object, allowing to structure a reality and preserving the Other's desire. The initial conceptualization emphasizes the holophrastic composition of the Other synthesis, marking a specificity of pluralization of $\mathrm{S}_{1}$, which differentiates it from schizophrenia. 
In the Seminar, Book 20: Mais, ainda Lacan circumscribes the characteristic of the master signifier, $\mathrm{S}_{1}$, not to reduce to any signifier, representing the subject in all speech levels by an external position that involves allowing the planning of the signifying chain. This plurality of $\mathrm{S}_{1}$, which takes you to remain "undecided between the phoneme, word, phrase, even all thought" (LACAN, 1972-1973 / 1982, p. 196), allows Lacan a homophonic a conceptual, named the "swarm" (essaim). Miller (1993) states that it is in schizophrenia we can see the hopelessly dispersed swarm of signifiers, with its phenomena manifesting the scattering and the disappearance of the master signifier.

Maleval notes that in autism, there is another form of pluralization in $\mathrm{S} 1$, and there is an order initiated by a coating process, an effect of the external position of the master-signifier. In an Other autistic synthesis there is a coordination of elements, but the reference is located internally in the very same significant system, not an outside point. Autistic-scholar is not represented by its Other synthesis, but attached to it. (MALEVAL, 1997).

The author illustrates the operation of the Other synthesis with the exploits of autistic-scholars who both delight the laity. Therefore, attributed to the Other synthesis is the extraordinary memory of Raymond, the autist in the movie Rain Man ${ }^{10}$, who memorizes the numbers of the entire phone book and his the ability to quickly count the cards in a deck. The Other synthesis is not barred; however, it is organized, ordering some fields of reality, and finds enjoyment in the subject.

Attaching to your Other synthesis, the autistic subject turns to it and it turns off voluntarily. The protective action of this object allows the development of significant alienation, accentuating the animation of the libido and the effects of appeasement of enjoyment.

It does not operate, however, the separation process. Defined as autistic defense by a return of enjoyment over the edge, according to the formula proposed by Éric Laurent, it allows a separation of paranoid and schizophrenic mechanisms. (Maleval, 1997, p. 137)

The proposal, drawn from Laurent (1992/1998), a joy that returns over the edge, will be further enhanced and developed by Maleval. In contrast, the hypothesis of an elaboration of the significant alienation, promoted by S1, will be abandoned by him. Maleval (2011) goes on to state that there is a difficulty of

10 LEVINSON, B. (Dir.) (1988) Rain Man. United States, MGM/UA. Movie with Dustin Hoffman in the lead role. 
the subject to take an enunciation position, marking their refusal to be alienated. Autists only partially access significant alienation.

Also his conception of a composite synthesis of the Other consists of a cluster of $\mathrm{S} 1$ ordered, but without a rectified external reference. The absence of "at least one" significant other to order the others removes the logic of their operation, which implies the need for an external element. To address this conceptual impropriety, Maleval (2009) recognized the notion of sign, replacing that of signifier.

The Other synthesis was composed of signs, whose nature allows the realization of a previously consecrated sense of independence to the signifier. Unlike this, the sign does not delete the object it represents, but it is closely related. The exact correlation representative with the thing represented, promoted by the sign, fixed its meaning and eliminates the need for a opposition signifier which defines it.

The maturing of the concept Other synthesis led to the reclassification of autistic objects. Essentially based on a protective function together with the expansion of interaction made possible by another synthesis, Maleval (2009) reduced to two the categories of autistic objects: simple and complex.

\section{THE AUTISTIC OBJECT: DYNAMIC AND ESSENTIAL}

Supporting descriptions of Tustin on the transitivist relationship with the autistic object, Maleval (2009, p. 169) argues that the autist's perception is, "willingly, as an object in the world of objects." Reports of Donna Williams (1994) demanding that they explain the subtle human expressions she didn't understand, the self-definitions of Temple Grandin, and the way he felt like "an anthropologist on Mars" (SACKS, 1995, p. 267), are a testimony to this. To see oneself as an object among others, indicates that experience is lifeless, reflecting the absence of functioning drive dynamics. Indeed, for those who work with autism, it is not difficult to see expressions of deregulation of the drive, as shown in the typical difficulties related to food, defecation, to see and speak.

Being an object, clinging to one, transitively, is the position of the autistic; it is your autistic object and this is part of your body. Extending the observations of Tustin, Maleval compares the game Fort-Da, transitional, with the behaviours on-off of autism. Both are ways to deal with the negativity of language and the pain of loss of the object (MALEVAL, 2009), but the first acts through significant opposition and the second through the sign. The Fort-Da realises successfully, the negativity of the thing, while the on-off behavior, under the operation of the sign, maintains its presence, even with constructed denial.

The spinning or flapping objects chosen by autists lead them to repetitive activity with such concentrated attention that they appear to be unaware of 
what is happening around them. These objects, named by Maleval as "simple autistic objects", provide a self-produced feeling engendered by their own body. In Freudian terms, the simple autistic object is no more than a autoerotic object.

Tustin already isolated the essential characteristic of the autistic simple object: its hardness. Noticing that the autistic seeks to integrate within themselves the characteristics of their object, Tustin demarcates its double function. It can be seen from the above that she interprets the choice of the rigidity of the object as a replica of the appearance of the autist's own body: hard and tense. This preference gives the autist a treatment for their body image. (MALEVAL, 2009).

The contribution of Maleval can reassess that of Tustin, affecting its conclusions. The author notes that the English psychoanalyst failed to identify another fundamental characteristic of the autistic object: dynamism. Their undeniable preference for objects, and not people, which the autistic attempts to animate. "It's about the double protection from which they seek joy which it permits." (MALEVAL, 2009, p. 167). It is the double side from which dynamism is sought.

The dynamic characteristics of objects - identified those that have movement (e.g. fans) or those that can be made to move (e.g. tops) — brings the animation that theautistdoes nothave. These dynamicobjectsarequitecommon among autistic objects and lend themselves to the self-treatment of animation instinctive of the autistic.

The hardness of the autistic object, the backbone of double protection, provides a remedy for the body image of the subject. To this imaginary is added instinctual animation, giving simple autistic objects a double life (Maleval, 2009, p. 172). The autoerotic sensation promoted by the simple autistic object is a barrier to the outside world and brings immediate protection against anxiety. If autoeroticism is its downside, the vital momentum that it provides becomes its positive side. It is here that we see the remarkable contribution of Maleval to the clinical aspects of the autistic object.

If this "double-life" participates in an island of competency ${ }^{11}$ or if it carries an organizational drive that binds the autistic to the world by way of the Other synthesis, it is considered a complex autistic object. This removes the enjoyment from the subject's body, locating it on a border, which not only makes a barrier to the Other, but above all, promotes a connection to social reality. The major function of the complex autistic object that does differentiate the simple autistic object is to "equip an instinctual enjoyment in excess" (MALEVAL, 2009, p. 170), providing the autistic with instinctual dynamics that they lack.

\footnotetext{
${ }^{11}$ Expression used by Maleval to indicate an area or subject that captures the autistic interest, for it being developed.
} 
If there is a quality common to all his [Joey's] objects (...) it is of course its ability to regulate the vital energy. Heused them totreathis affectivity. Theyarethe scavengers of libido, the enjoyment of regulators. Translating a subjective treatment work of the drives. This is a dynamic function neglected by Tustin. (MALEVAL, 2009, p. 177)

Furthermore the use of the squeeze machine of Temple Grandin, which she invented, is a real complex autistic object, that allows autists to calm themselves down in moments of anguish, and continue social interaction. Moreover, Grandin (1999) is categorical in stating that her life would not be possible without it.

Maleval (2009) notes that the squeeze machine and the livestock trap are not doubles of Grandin, but were built from it. Its parallel is found in animal welfare which makes use of them. Note, therefore, that the double is not confused with the complex autistic object, it being, however, a support. That was the mistake of Lefort, who reduced the complex autistic object to a simple double incarnation. A real double, has essentially a stopgap function. (MALEVAL, 2009, p.187).

The complex autistic object is always a creation of the subject, with rare exceptions. ${ }^{12}$ Maleval shows a progression of complexity, ranging from machine object, through similar constructions and reaching the imaginary friend. The latter shows up frequently in the testimonies of the high level autistics. The most complete form of the complex autistic object, according to Maleval is the mirror image. Donna Williams had access to this, after abandoning her imaginary friends.

Taking on an image in the magnified mirror, the double autistic enhances the me of the subject, his phallicization increases, but it is a phallicization that does not go through castration. The double scopic of Williams is not a total obstacle to all access to the lack of the Other, she notes that it does not lead to her being, sins for not being able to accomodate it in the field of the Other. It makes no more than one channel to the outside world: it involves narcissistic reflections, a solitude inhabited by her. He puts, however, the object gaze at a distance, captures it, and gives Williams the feeling of "not fully experiencing being alive." (MALEVAL, 2009, p. 188)

The complex autistic object composes the reality of autists. It is through its metonymical derivation that they invest the world and its objects. The same operation holds the relationship of autism to language, where they objectify signs.

\footnotetext{
${ }^{12}$ Examples of complex objects autistic adopted, not created by the subject, in an exception level, televisions or washing machines. This was the kind of complex object that served Charlie, the boy attended by the French psychoanalyst Myriam Perrin, whose case report describes an elaborate way from the simple autistic object to the autistic object complex.Cf. PERRIN, M. (2009) “Construction d'une dynamique autistique. De l'autogire à la machine à laver. "In Maleval, J.-C. (dir.). L'Autiste, son double objets et ses. Rennes, FR: Presses Universitaires de Rennes, p. 69-100.
} 
With its border-object, the autist comes to castration, through an imaginary elaboration of symbolic loss. The autistic object, according to Maleval (2009, p. 189), "can sometimes imitate it [the object], but not realize it."

\section{CONCLUSION}

The clinical question raised by the place of the autistic object is of essential importance for treatment. No exit because the autistic object is always present. Thus, it can be said clinically that the autist entangles the clinician in the autistic object.

If it is taken only by its dual "hard" aspect, the tendency is to consider it harmful to treatment, because they are inside its protective function, but also detached. That was the deception suffered by Tustin and by Lefort.

However, if it is seen as a dynamic dual aspect, new clinical perspectives open up. If the spontaneous movement of the autist to bind to the autistic object, can be turned off, it brings a regulator to the libidinal economy. A complexity of libidinal animation function through an organization of reality promoted by the Other synthesis, or the establishment of an axis of knowing that captures the autistic interest, allowing its connection to the world. Through the use of the autistic complex object the autist can come to dominate symbolic loss.

Witness the transition of the autistic object, impregnated with its protective function, in relation to the outside world, "not-me", to the connector object to this world, built on that initial base, through the intricate work of the subject.

Accompanying the autist to the most elaborate constructions of their objects, the analyst remains a partner of the subject, identifying their special objects and favoring the treatment that the autist gives them.

In seeking to clarify the proposal of Lacanian psychoanalysts who develop a line of treatment through the autistic objects, it is important to attempt to impose policy that creates an educational therapeutic hegemony. This article portrays the richness of theoretical elaboration in the clinic, the result of long dedication by psychoanalysts in the treatment of autism. The inherent clinical difficulties lie in autistic resistance to consenting to their presence and the demands of the Other, which lead them to use the objects. Even adaptive approaches are faced with the question of surpassing these therapeutic limitations.

Psychoanalysis defends the plurality of treatments availableto autists and their parents, offering them the opportunity to follow the subjective work that autists undertake to keep a safe distance from that which invades and annihilates. For them, it extends their knowledge about the libidinal organization of autism and interventions that aim to help them to escape the radicality of their defenses. 


\section{REFERENCES}

GRANDIN, T. (with the collaboration of M. Scariano) (1999) Uma menina estranha. Autobiografia de uma autista. Transl. S. Flaksman. São Paulo: Companhia das Letras.

LACAN, J. (1972-1973/1982) O seminário, livro 20: Mais, ainda. Rio de Janeiro, Jorge Zahar.

LAURENT, É. (1992/1998) Reflexiones sobre el autismo. Anamorfosis, v.5, n.5, jun. Buenos Aires: EOL, p. 85-94.

LAURENT, É. (2012) "O que nos ensinam os autistas", in MURTA, A., CALMON, A. \& ROSA, M. (Orgs.) Autismo(s) e atualidade: uma leitura lacaniana. Belo Horizonte: EBP/Scriptum, p. 17-44.

MALEVAL, J.-C. (1997) Ébauche d'une approche de la spécifité de la psychose autistique. Bulletin Groupe Petite Enfance, n. 10, jan., L'Autisme. Paris: Nouveau Réseau Cereda Diagonale Francophone, p. 136-138.

MALEVAL, J.-C. (1998) La machine autistique de Temple Grandin. La Cause freudienne. Nouvelle revue de psychanalyse, n. 38, feb., Noveaux symptômes. Paris: Navarin, p. 98-102.

MALEVAL, J.-C. (2009) "Les objets autistiques complexes sont-ils nocifs?", in MALEVAL, J.-C. (dir.) L'autiste, son double et ses objets. Rennes, FR: Presses Universitaires de Rennes, p. 161-189. (Clinique Psychanalytique et Psychopathologie).

MALEVAL, J.-C. (2011) Langue verbeuse, langue factuelle et phrases spontanées chez l'autiste. La Cause freudienne. Nouvelle revue de psychanalyse, n. 78, jun., Des autistes et des psychanalystes. Paris: Navarin, p. 77-92.

MILLER, J.-A. (1993) "Esquizofrenia y paranoia", in BROCA, R. et al. Psicosis y psicoanálisis. Buenos Aires: Manantial.

PIMENTA, P. (2003) Autismo: déficit cognitivo ou posição do sujeito? Um estudo psicanalítico sobre o tratamento do autismo. Masters Dissertation, Programa de Pós-Graduação em Psicologia, Faculdade de Filosofia e Ciências Humanas, Universidade Federal de Minas Gerais, Belo Horizonte. Available in: http://www.bibliotecadigital.ufmg.br/dspace/bitstream/handle/1843/BUOS-96TKC6/disserta__opaulapimenta2003. pdf?sequence=1. Access: 11 aug. 2015.

PIMENTA, P. (2012) O objeto autístico e sua função no tratamento psicanalítico do autismo. Doctoral Thesis, Programa de Pós-Graduação em Psicologia, Faculdade de Filosofia e Ciências Humanas, Universidade Federal de Minas Gerais, Belo Horizonte. Available in: http://www.bibliotecadigital.ufmg.br/dspace/bitstream/handle/1843/BUBD-9V5PRZ/ tesepaulapimentacompleta_20.03.15.pdf?sequence=1. Access: 11 aug. 2015.

SACKS, O. (1995) “Um antropólogo em Marte”, in Um antropólogo em Marte. Sete histórias paradoxais. 3. ed. Rio de Janeiro: Companhia das Letras, p. 253-301.

TUSTIN, F. (1972/1975) Autismo e psicose infantil. Transl. I. Casson. Rio de Janeiro: Imago.

TUSTIN, F. (1981/1984) Estados autísticos em crianças. Transl. J. M. Xisto. Rio de Janeiro: Imago. 
TUSTIN, F. (1986/1990) Barreiras autísticas em pacientes neuróticos. Porto Alegre: Artes Médicas.

TUSTIN, F. (1995) A perpetuação de um erro. Letra Freudiana, year 14, n. 14, O autismo. Rio de Janeiro: Revinter, p. 63-79.

WILLIAMS, D. (1994) Nobody nowhere. London, UK: Jessica Kingsley.

\author{
Paula Ramos Pimenta \\ paularamos.pimenta@gmail.com \\ Jésus Santiago \\ jesussan.bhe@terra.com.br \\ Ana Lydia Santiago \\ analydia.ebp@gmail.com
}

Traduzido do português por Paul Taylor Shafee/translated from portuguese by Paul Taylor Shafee 
Projeto gráfico e diagramação

Areté Programação Visual

Anita Slade

Sonia Goulart

\section{Revisão}

Sonia Cardoso

Doris Dana

Tipografia utilizada

Joana MT, Boton regular,

Univers e Univers condensed

Produzida em abril de 2016 
